\title{
Movimentos das Águas Caboclas: narrativa visual, cotidiano e ruptura na comunidade pesqueira de Regência Augusta-ES*
}

\author{
Cabocla waters movement: visual narrative, daily life \\ and rupture in the fishing community of Regência \\ Augusta-ES
}

\author{
Charlene Sales Bicalho ${ }^{1}$ \\ Aline Trigueiro ${ }^{2}$ \\ Winifred Knox ${ }^{3}$ \\ Ricardo Behr ${ }^{4}$
}

Palavras-

chave:

Regência Augusta;

Pesca artesanal;

Fotografias;

Cotidiano;

Ruptura.
Resumo: $O$ presente artigo tem 0 interesse de refletir sobre os processos de mudança social em curso na vila de Regência Augusta (localizada no município de Linhares-ES). Visa problematizar a relação entre o cotidiano da atividade pesqueira e os elementos de ruptura que estão ganhando forma na vida desta pequena localidade, palco de instalação de projetos modernizadores, sobretudo de cunho econômico, como por exemplo, o petróleo e a celulose. Por meio de uma escrita ensaística, o texto acolhe a imagem fotográfica enquanto procedimento reflexivo e de observação, e também de aproximação e diálogo com os(as) pescadores(as) do lugar. Os resultados da pesquisa revelam algumas mudanças já em curso na prática da pesca artesanal, no entanto não desconsideram as formas de resistência e de reafirmação dessa cultura na própria configuração do cotidiano local.

\footnotetext{
* Artigo recebido em 25/03/2013 e aprovado para publicação em 29/03/2013.

1 Mestre em Administração/UFES e Fotógrafa. Todas as fotografias apresentadas neste artigo são de sua autoria. E-mail: bicalho.charlene@gmail.com.

2 Dra. em Sociologia. Professora do PGCS/DCSO/UFES. Coordenadora do GEPPEDES (Grupo de Estudos e Pesquisas em Populações Pesqueiras e Desenvolvimento no ES). E-mail: aline.trigueiro@uol.com.br.

3 Dra. em Ciências Sociais. Professora do PGCS/DCSO/UFES. Coordenadora do GEPPEDES. Email: winknox@hotmail.com.

4 Dr. em Engenharia de Produção. Professor do PPGAdm e do PPGGP/UFES. E-mail: ricardobehr@hotmail.com.
} 
Keywords: Abstract: This article intends to think about the process of social Regência Augusta; change under way in the village of Augusta Regency (located in Linhares-ES). It proposes to debate the relationship between the daily Small-scale fishing activity; Photographs;

Daily life; Rupture. life of the fishing activity and the breakthroughs that are gaining shape in city life; mainly those from economic modernization projects (oil extraction and cellulose). Through an essayist approach, this study considers the photographic image as a reflexive process and an observation point, and an instrument that promotes a dialogue with the local fishermen. The results of this investigation reveal some changes arising in the small-scale fishing activity, although at the same time there are some forms of resistance and reaffirmation of this culture on the local everyday life.

\section{Primeiras águas}

Fotografia 1: Índio e Cidi retirando a rede de espera do mar

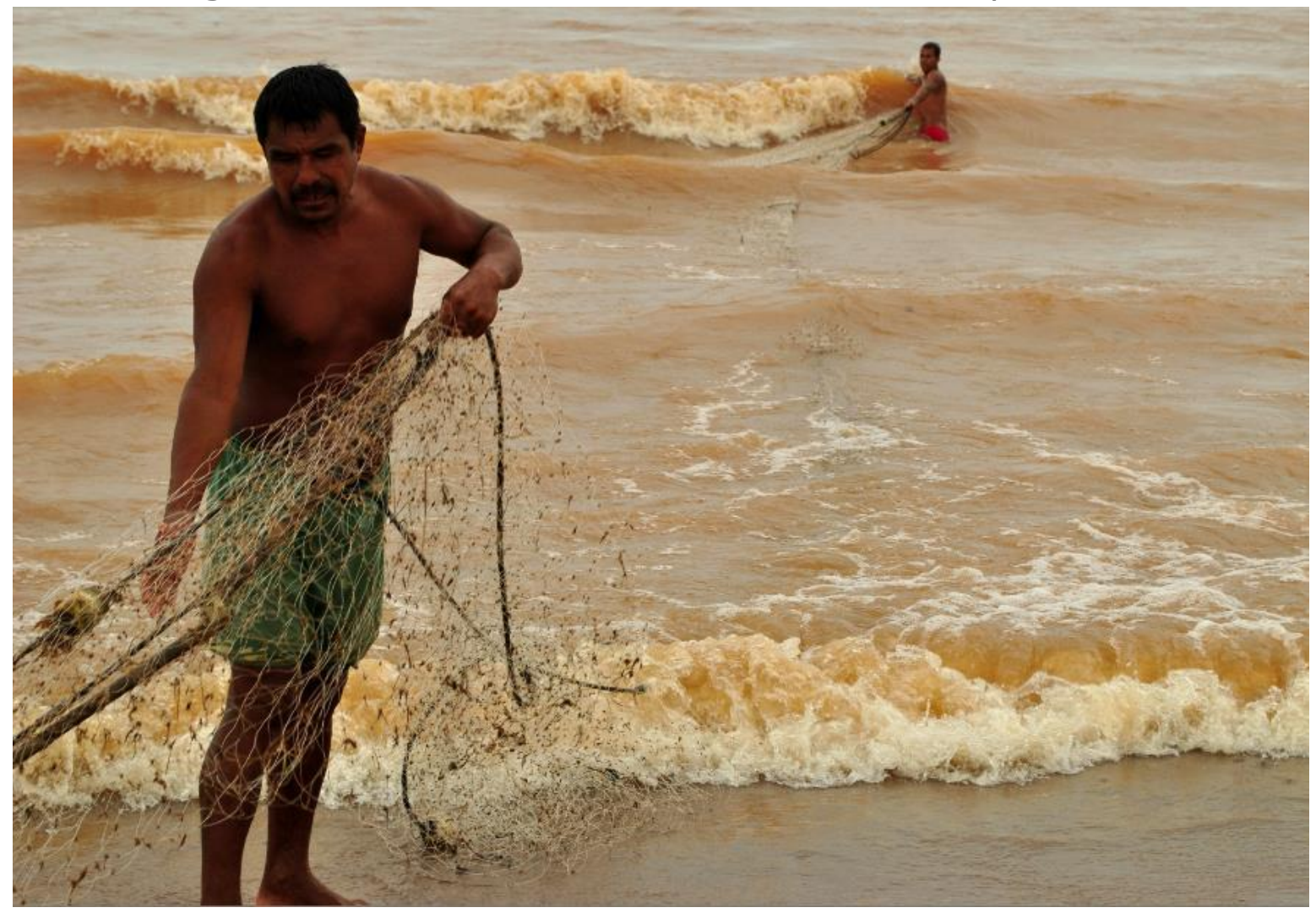

Foto: Charlene Bicalho. Regência/ES em 13/04/11. 
$\mathrm{O}$ presente artigo expõe um recorte do acervo de imagens que foi reunido durante a pesquisa participante realizada pela primeira autora deste artigo no período em que desenvolveu a sua dissertação de mestrado ${ }^{5}$, na Vila de Regência Augusta-ES, tendo como suporte a fotografia. Tem por proposta analisar o cotidiano da atividade pesqueira nessa vila, contextualizando e problematizando as alterações que esse modo de vida sofre por conta de atividades econômicas de grande porte - dentre elas a extração de petróleo e celulose - que chegam a esse lugar.

Iniciado em 2010, o trabalho fotográfico fitou - inicialmente com um olhar estrangeiro - a pequena vila de pescadores, composta por 288 famílias. Durante cerca de dezoito meses, seja andando pelos rios e mares ou navegando pelas ruas de Regência Augusta, captou-se a indistinção entre a arte e a vida; os laços familiares e de amizade; as habilidades e técnicas refinadas que humanizam o mar; as lutas travadas entre o homem e o peixe pela sobrevivência; os afazeres femininos no trato do pescado junto com os filhos nos quintais; os pescadores que carregam o mar nas mãos; os olhos mirando a incerteza da chegada.

Por meio da fotografia foi possível então vivenciar os espaços, os tempos, os outros e o mesmo... Inicialmente, as imagens foram produzidas com um olhar vislumbrado, ainda sob o impacto das primeiras visões, depois a temática da pesca emergiu com o amadurecimento do tempo, movida pelo novo desafio, qual seja, o de tentar conciliar a estética e a documentação do cotidiano de homens e mulheres que se lançam à incerteza do presente, durante suas pescarias no rio Doce e no mar.

\section{Cotidiano na fotografia em campo: composições e recortes}

Várias são as formas e o uso da linguagem fotográfica em pesquisas no âmbito das Ciências Sociais. Não pretendemos aqui adentrar essa vasta multiplicidade, pois que exigiria de nós uma análise mais amiúde, a qual tornase limitada pelos propósitos desse artigo, entretanto, podemos destacar alguns caminhos privilegiados até então. O mais evidente seria o uso da fotografia como um instrumento de coleta e de registro de dados (KANT, 1997; CRANE, 1984; COLLIER, 1986), cujo enfoque tem privilegiado o fator de aproximação e

\footnotetext{
5 Trabalho realizado no PGadm/UFES sob a orientação do Prof. Dr. Ricardo Roberto Behr e coorientação da Profa. Dra. Aline Trigueiro.
}

Caderno eletrônico de Ciências Sociais, Vitória, v. 2, n. 1, p. 19-42, 2014. 
de troca que este instrumento acaba realizando com os sujeitos pesquisados e o pesquisador. Não obstante, outras propostas têm utilizado a fotografia como uma metodologia de rememoração e compartilhamento de experiências visuais e pessoais (ALVES, 2004; KNOX, 2007; 2011), permitindo um aprofundamento dos aspectos simbólicos e das expressões estéticas dos grupos pesquisados. Há, ainda, aqueles trabalhos que buscam, através da fotografia e dos recursos imagéticos, a construção de uma linguagem visual que detenha a possibilidade da construção de uma narrativa ou uma organização em textos visuais (GODOLPHIN, 1995; LEITE, 1998; SAMAIN, 1994).

No presente artigo, utilizou-se a imagem fotográfica não apenas como um meio para a observação do lugar, mas no seu misto de possibilidades, ou seja, ao mesmo tempo como registro, rememoração e construção de textos visuais (ALVES, 2004; KNOX, 2009; CHARLENE, 2012). Na experiência de aproximação etnográfica com a comunidade de pescadores de Regência Augusta, o uso da imagem funcionou também como uma forma de criação de relações mais próximas, amigáveis, tanto quanto um fator de entrada e possibilidade de troca entre os saberes. Embora de forma assistemática, as fotografias, quando devolvidas aos sujeitos fotografados (e na grande maioria todas foram devolvidas), serviram como desencadeadoras de lembranças e memórias, que eram, na medida do possível, registradas. Foram ainda realizadas exposições fotográficas na e para a comunidade ${ }^{6}$, com isso, tentouse construir algumas narrativas (textos) visuais sobre o modo de vida pesqueiro em Regência.

Considerando a temática que norteia o título deste trabalho - a relação dinâmica entre cotidiano e ruptura - percebe-se que o uso da fotografia foi capaz de se inserir nesse movimento. A fotografia tornou-se, por esta via, ao mesmo tempo uma forma de captura do cotidiano pelo olhar emoldurante e emoldurador do fotógrafo, e uma interferência, por conta da presença do mesmo no local (com as suas lentes e a sua máquina fotográfica). Ou seja, a experiência imagética foi capaz de produzir uma ruptura nesse cotidiano pesquisado, de modo que o trabalho do fotógrafo constitui-se não apenas como um exercício de interpretação, mas também de produção da realidade fotografada, ao organizar as suas composições e os seus recortes.

Assim sendo, para compor a narrativa visual apresentada neste artigo, foram selecionadas imagens sobre o cotidiano da pesca e as diversas

${ }^{6}$ As fotografias também foram expostas em encontros acadêmicos.

Caderno eletrônico de Ciências Sociais, Vitória, v. 2, n. 1, p. 19-42, 2014. 
modalidades de pescaria praticadas pelos pescadores em Regência Augusta. 0 recorte escolhido trouxe para o primeiro plano de referência as mãos, o fazer, os instrumentos de captura do peixe e o processo social de trabalho. Ampliando essa leitura social e estética do lugar, também são apresentadas imagens que evidenciam os espaços onde os pescadores e seus familiares transitam em terra, suas brincadeiras e a arquitetura local, e que dão o tom da vida, das relações sociais, ou seja, da atmosfera cultural na vila de Regência. Por meio dessa seleção de imagens, espera-se poder contar um pouco sobre o cotidiano do lugar e os seus atuais processos de mudança social.

\section{A pesca artesanal: cotidiano e rupturas}

A pesca artesanal faz parte do cotidiano de diversas vilas pesqueiras, não só como fonte de alimento, mas também como modo de vida, fornecendo identidade a essas comunidades. Segundo Diegues (1999), várias culturas litorâneas ligadas à pesca como o jangadeiro (encontrado em todo o litoral nordestino, do Ceará até o sul da Bahia), o caiçara (no litoral entre o Rio de Janeiro e São Paulo) e o açoriano (no litoral de Santa Catarina e Rio Grande do Sul) se constituíram a partir de atividades pesqueiras.

No caso de Regência Augusta a dinâmica da pesca não é diferente das experiências vividas em outras vilas. Durante os meses de convívio nessa localidade, os olhos mareados puderam circunavegar outros modos de recontar as formas sensíveis de expressão dos fazeres e dos ofícios dos moradores daquele pequeno lugar. Assim foi que o cotidiano local revelou-se enquanto continuidade na extensão do gesto manual e na sua relação com o mundo, ao mesmo tempo em que a atividade pesqueira - por sua relação intrínseca com o mar, com o rio e as suas condições de uso e acesso - constituía-se também enquanto indeterminação, espaço aberto à transformação, dando-se também enquanto ruptura.

- "Nem parece Regência!". Por meio dessa fala do pescador P.7, identificamos a transfiguração do cotidiano que o registro fotográfico produz. As sensações provocadas tanto no fotógrafo quanto naquele que se vê na fotografia descortinam um estranhamento, mas também um reconhecimento,

\footnotetext{
7 Nos trechos citados das entrevistas optou-se por colocar apenas a primeira letra do nome dos entrevistados, para não os expor. Entretanto, na legenda das fotos, optou-se por colocar a referência verdadeira dos nomes dos pescadores.
}

Caderno eletrônico de Ciências Sociais, Vitória, v. 2, n. 1, p. 19-42, 2014. 
possibilitando o estabelecimento de uma troca nesse encontro do belo com as práticas cotidianas. Um rompimento com o hábito naturalizado.

Fotografia 2: Hermínio (à direita), Audir (à esquerda) retirando as manjubas da rede

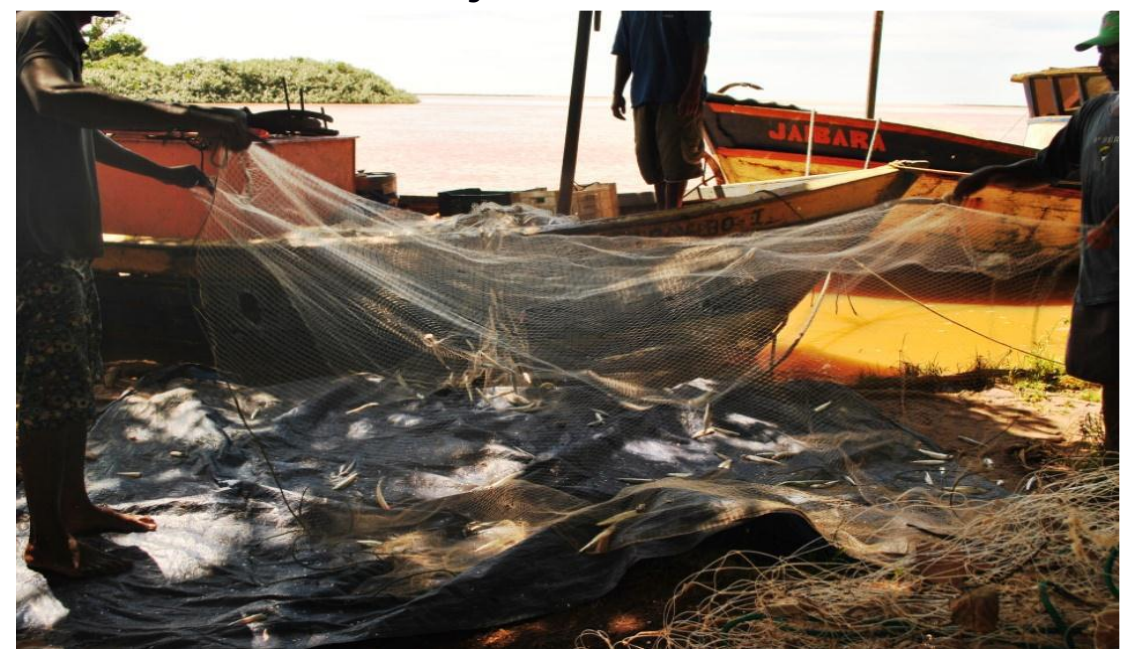

Foto: Charlene Bicalho. Regência/ES em 13/04/11.

Fotografia 3: Casas antigas da Vila

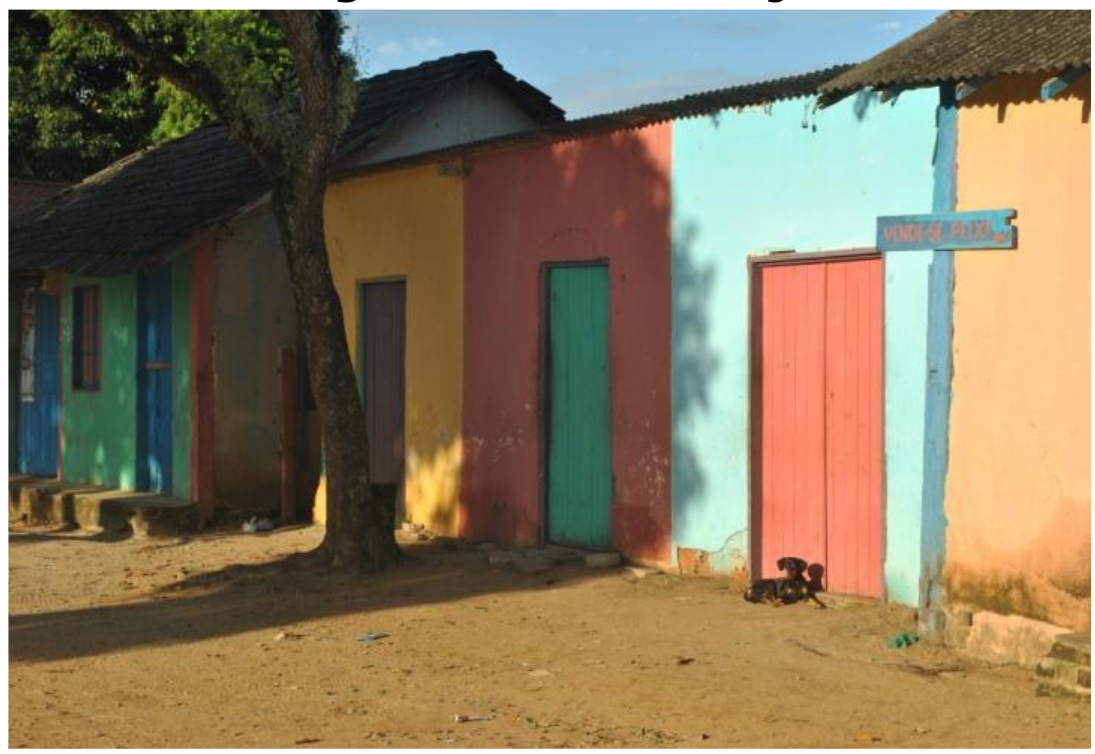

Foto: Charlene Bicalho. Regência/ES em 08/04/11. 
Fotografia 4: Hermínio retirando rede de pesca do rio Doce, durante pescaria de rede de espera

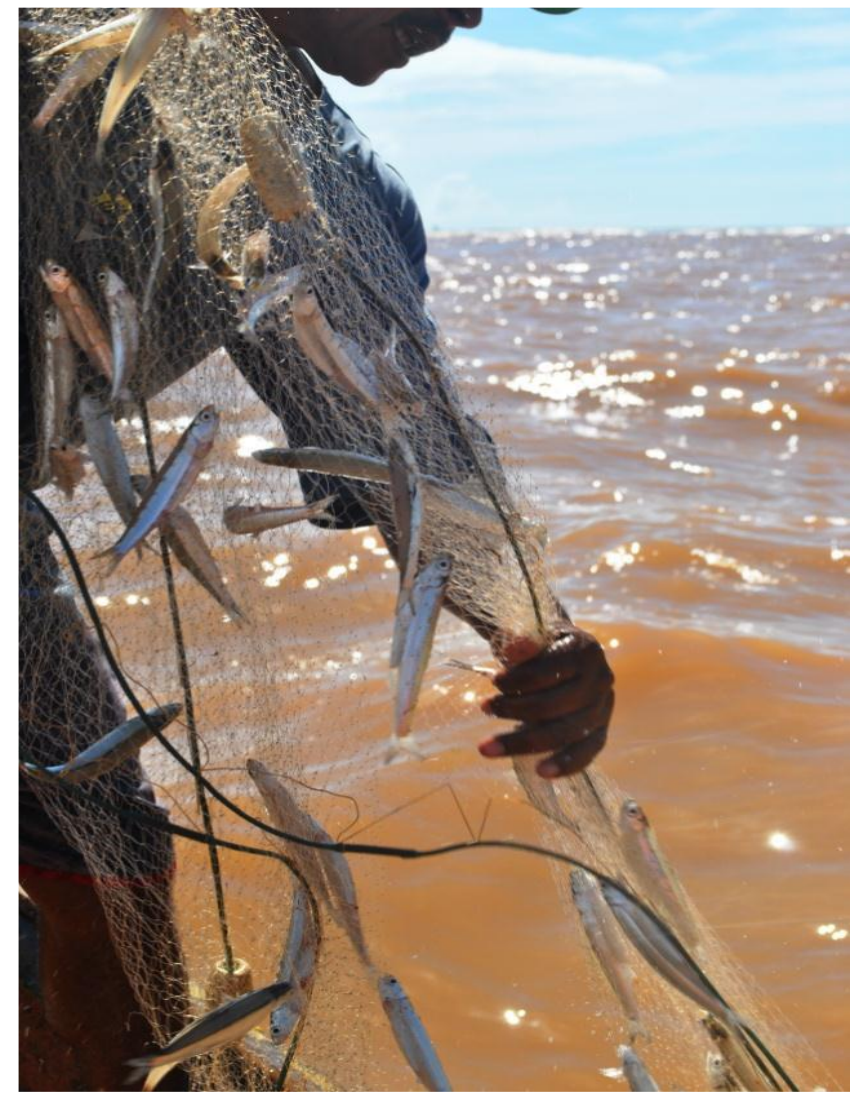

Foto: Charlene Bicalho. Regência/ES em 13/04/11.

As imagens e o simbolismo das cores dão forma à história local, reescrevendo assim a realidade do fotógrafo, do fotografado e do espectador da fotografia. As cenas e cenários escolhidos ocultam ao mesmo tempo em que revelam suposições da vida diária que fazem parte do imaginário coletivo, e evidenciam a força e a intensidade do fazer, as linhas e as formas que levam o olhar em busca de sentido.

Amiúde, narra-se as asperezas e o encantamento do viver cotidiano. No trançado da pesca tem-se uma possibilidade da fartura, mas também do ocaso: a rede, o anzol, o balão, o jequiá, não só capturam peixes, mas a vida, o mar, o retorno da jornada, sua alegria ou o silêncio. Um devir que a lente da câmera ousou tentar captar.

Esse cotidiano é tecido então com os fios da vivência e do trabalho, e também do lazer, do suor e das lágrimas. Nesse emaranhado as mãos tornamse meios para essa realização, são artefatos naturalizados, representam o 
corpo em conexão com o meio, a expansão do humano... Permitindo, assim, a união entre o natural e o cultural.

Fotografia 5: Pescador Abel iscando o espinhel com manjuba

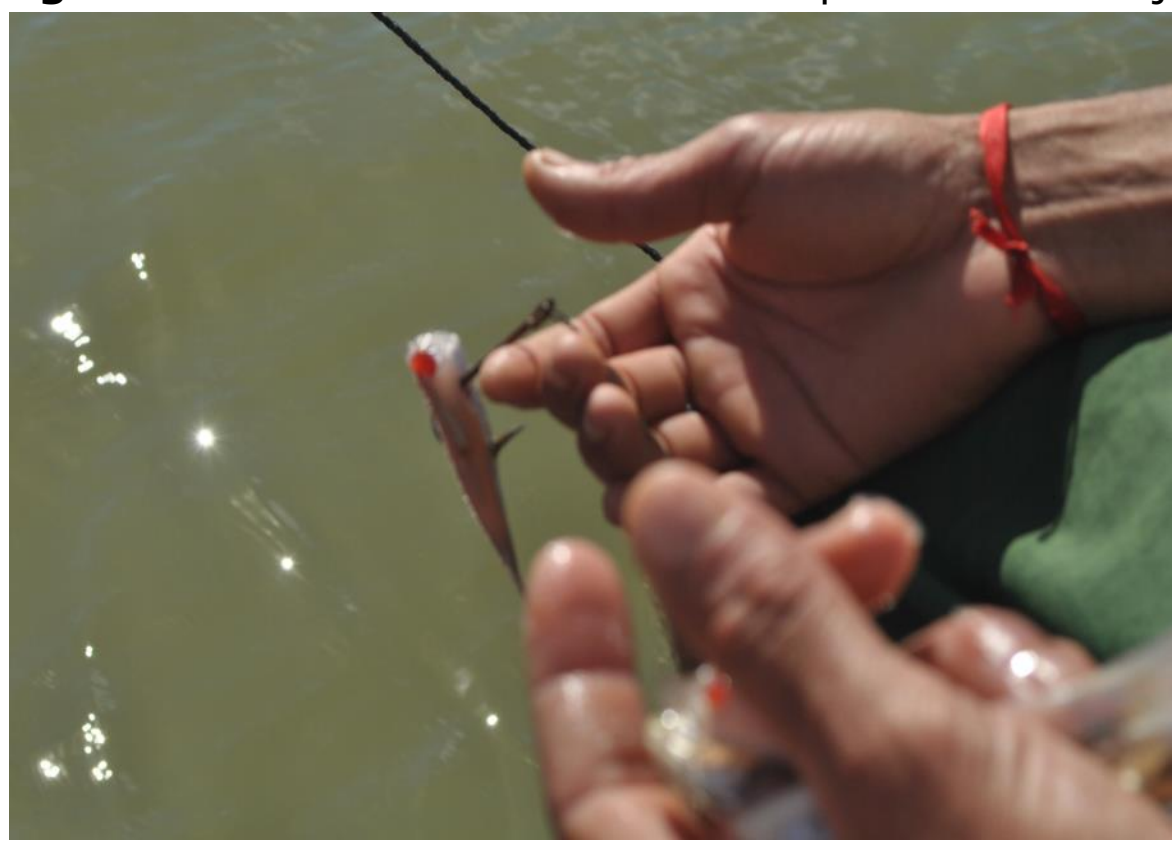

Foto: Charlene Bicalho. Regência/ES em 16/07/11. 
Fotografia 6: Pescadora Paloma conduzindo a embarcação

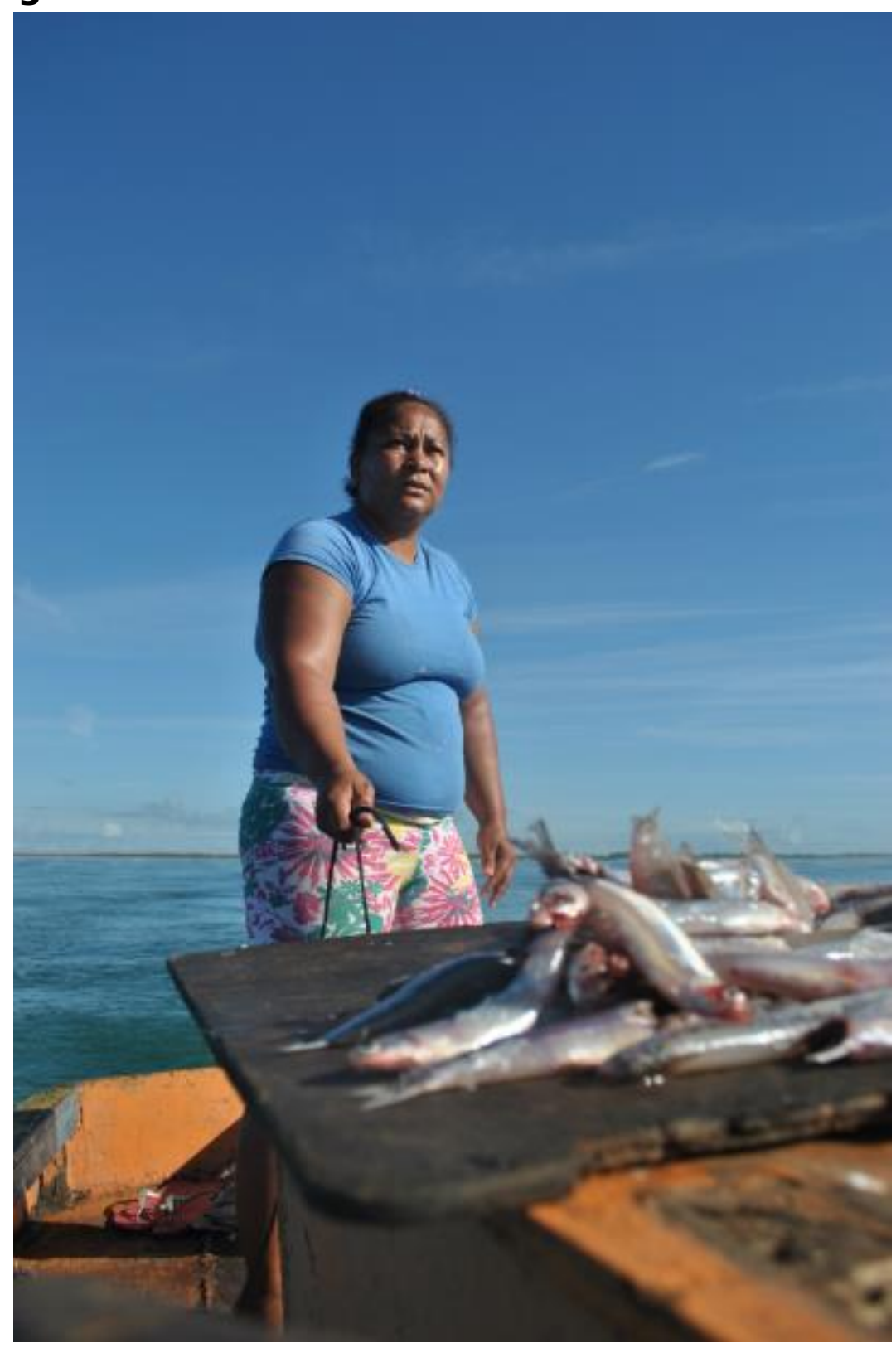

Foto: Charlene Bicalho. Regência/ES em 03/04/12.

Nessa interação - entre o cultural e o natural - configuram-se práticas e saberes, cosmovisões que constituem a vida desses pescadores artesanais. Trata-se de um saber reconhecidamente naturalístico ${ }^{8}$, produzido nesse

\footnotetext{
8 Saberes de domínio das populações tradicionais, cultivados pelas mesmas nas suas vivências e nos seus processos de trabalho em interação com a natureza. Ou seja, um tipo de saber que
} 
intercurso de mãos e corpos, artefatos e natureza. Assim, nesse cotidiano se tece o destino do pescador, um destino trançado no balanço do barco, no lançamento da rede; um modo de vida que se encontra lá... Entre o movimento das águas do rio e das ondas do mar.

\section{Um pouco da história da vila: cotidiano de ontem e de hoje}

Durante a ocupação do Espírito Santo pelos portugueses, na procura por riquezas, ouro e pedras preciosas, as estradas hidrográficas eram as únicas vias de acesso do litoral ao interior e vice-versa. Por conta desse aspecto o rio Doce se fez de extrema relevância na história da vila de Regência Augusta. Ele nasce na Serra da Mantiqueira, Minas Gerais, e atravessa o estado do Espírito Santo de oeste para leste, percorrendo 202 municípios, vindo a desaguar entre as vilas de Povoação e Regência Augusta. Seu nome foi dado pela esquadra portuguesa em $1501^{9}$, que encontrando água doce defronte à foz do rio, chamaram-Ihe então rio Doce.

As dificuldades de navegação nas águas do rio Doce, aliadas à construção da ponte Getúlio Vargas ${ }^{10}$ em 1954, tornaram as estradas fluviais dispensáveis. Até 1960 o baixo rio Doce não passou de uma fronteira agrícola fornecedora de alimentos para as cidades industriais. A vila de Regência Augusta, formada etnicamente por $\operatorname{caboclos}^{11}$, entrou em declínio tendo em vista que o escoamento das mercadorias foi transferido para as estradas rodoviárias. Dessa forma, a comunidade vivenciou um processo de exclusão socioeconômica.

A pesca, nesse contexto, era inicialmente praticada como fonte de subsistência, sendo realizada de forma ainda rudimentar, utilizando-se de técnicas herdadas dos povos indígenas. As pescarias eram realizadas em canoas, com redes confeccionadas com linha de barbante e boias de madeira, gruzeiras ${ }^{12}$, mijuadas ${ }^{13}$, tarrafas e linha de mão feita de tucum ${ }^{14}$. Outras

se constrói coletivamente a partir dessa interação. Ver, entre outros, Descola (2000) e Roué (2000).

9 Esquadra comandada pelo navegante André Gonçalves (ZUNTI, 1941).

10 Ponte sobre o rio Doce.

11 Miscigenação entre os índios moradores da barra sul do rio Doce e negros vindos do município contíguo, São Mateus, localizado mais ao norte do ES (ZUNTI, 1941).

12 Uma corda esticada de uma vara a outra, anzóis presos a linhas de mais ou menos meio metro, pendentes nessa corda e enfileirados em distância regular.

13 Atualmente chamada de rede de espera.

14 Tarrafa feita de cipó. 
formas de se capturar peixes abundantes na época eram o quitandu ${ }^{15}$, a camboa ${ }^{16}$ e o jequiá ${ }^{17}$ utilizado para a pesca no rio do camarão pitu e lagosta.

A localização das residências mais antigas da Vila, próximas à foz do rio Doce e à foz do rio Preto ${ }^{18}$, indica onde a pesca predominava em tempos áureos. Hoje, os pescadores necessitam ir para o mar em busca do pescado que está escasso nos estuários. De acordo com o entrevistado E. (2011), pescador, "[...] antigamente a gente ia pro mar de canoa, mas era como uma brincadeira porque nem precisava; com uma tarrafada no rio Doce a gente pegava muito peixe, hoje em dia não $[\ldots] "$.

As pescarias realizadas no rio Doce ganharam grande relevo nos relatos colhidos dos pescadores mais antigos. Herdada dos índios, tal modalidade era praticada por água, diretamente no ato do lanço ${ }^{19}$, sendo desnecessária a prática da pescaria de rede de espera. Ou seja, um tipo de pescaria que "envolve um conhecimento sistematizado sobre seu objeto de trabalho e sobre as condições naturais que interferem diretamente nessa atividade" (BRITTO, 1999, p. 77).

Fotografia 7: Pescadores Veneno, Roni e Cidi pescando no rio Doce

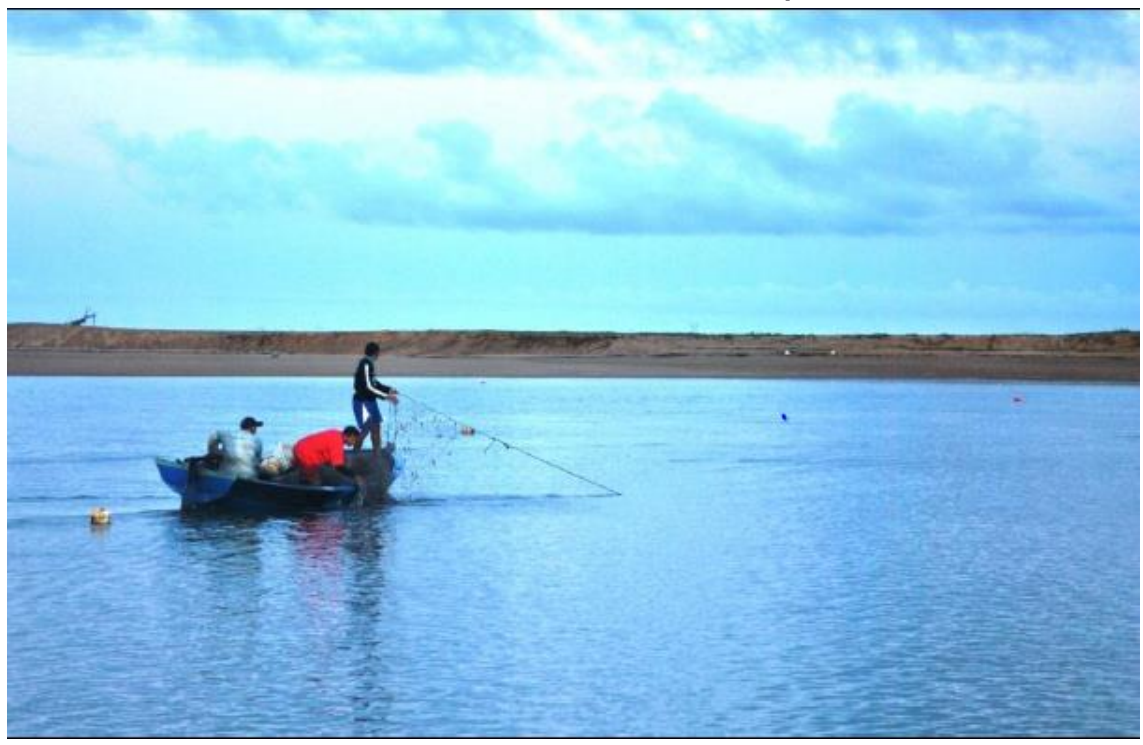

Foto: Charlene Bicalho. Regência/ES em 14/07/11.

\footnotetext{
${ }^{15}$ Armadilha afunilada.

16 Cercado de madeira onde o peixe entrava na maré cheia e ficava preso na maré baixa.

17 Confeccionado em taquara.

18 Afluente do rio Doce.

19 Sem utilização de embarcações.
} 
Segundo relato do entrevistado G. (2010), pescador, "[...] antes a gente pescava com rede de barbante, isso eu devia ter uns 17 anos. Era pesado precisava de 3 a 4 pessoas para segurar. Pescava com rede de lanço ${ }^{20}$ dentro do rio Doce também. Não precisava deixar a rede esperando no rio, era só jogar que vinha aquele monte de peixe $[\ldots] "$, diz ele. Outras modalidades também eram praticadas na época como linha de mão e com rede de barbante embarcado 21 .

Tais alterações, identificadas nas formas de trabalho ao longo da história da vila, espelham os rearranjos sociais, os modos segundo os quais os moradores da pequena cidade têm lidado com os elementos de mudança que redesenham o seu cotidiano: os processos migratórios, a urbanização, a implantação de grandes projetos de desenvolvimento econômico e as alterações geradas no meio biofísico, de onde retiram o seu sustento. Destacaremos, a seguir, alguns aspectos desse processo de mudança em Regência Augusta.

\section{Mudanças e rupturas no presente}

A pescaria artesanal em Regência Augusta atualmente é realizada tanto na região estuarina 22 quanto no mar. As modalidades de pesca realizadas são: pesca de rede de espera com barco ou sem barco, realizada tanto no rio como no mar; caceio ${ }^{23}$ realizado no rio; espinhel ${ }^{24}$ realizado no mar; arrasto de camarão, realizado no mar; tarrafa 25 com barco ou sem barco, realizada tanto no rio quanto no mar; e linha de mão, realizada tanto no rio quanto no mar.

\footnotetext{
20 Cerca de três pescadores com bote a remo jogam de duas a três redes emendadas no rio. Enquanto um fica na água segurando o calão, um fica no bote remando em direção à praia enquanto o outro joga a rede.

${ }^{21}$ Duas canoas pareadas com a rede de barbante no meio.

22 Região de ambiente aquático transicional entre o rio Doce e o Oceano Atlântico, geralmente com elevada produtividade biológica devido aos nutrientes que as águas de terra transportam.

23 Modalidade de pesca que consiste na captura dos peixes que vêm do mar para desovar no rio.

24 Modalidade de pesca na qual são utilizadas pedras em que se colocam flutuadores em conexão com a linha principal. O flutuador possui sempre uma bandeira para facilitar a localização. A distância entre uma linha secundária e outra deve ser suficiente grande para evitar o entrelaçamento de anzóis uns com os outros. O comprimento da linha principal é em consequência do número de anzóis, pode ser até de quilômetros e de centenas de anzóis e neste caso há necessidade de se usar um maior número de flutuadores e âncoras.

25 Modalidade de pesca realizada com uma rede de pesca circular com pequenos pesos distribuídos ao seu redor.
} 
Como se trata de uma atividade que não é passível de realização sem a interação com os elementos da natureza, ou seja, os recursos do ambiente entendido aqui como o espaço biofísico e cultural no qual se estrutura o ofício da pesca artesanal - quaisquer impactos sofridos nesse espaço retornam na forma de alterações e rupturas nos modos de fazer dessa atividade. Assim tem acontecido com as pequenas vilas, surpreendidas por processos modernizadores e as suas chamadas externalidades socioambientais.

Ao contrário da atividade pesqueira industrial - cujas técnicas de captura do pescado são amparadas por recursos tecnológicos sofisticados, e cuja capacidade de captura e de armazenamento do pescado só é possível por conta de uma frota com grandes barcos - a pesca artesanal se constitui por embarcações de pequeno porte, sendo praticada de forma autônoma, na maioria das vezes como atividade familiar. Trata-se de um tipo de pesca que se apresenta ainda como organizadora das demais dimensões da vida social, norteando hábitos alimentares, festividades, formas de solidariedade e de negociação.

Hoje, em Regência Augusta, o rio Doce, que é uma fonte de recursos para a comunidade pesqueira, encontra-se ameaçado pela pressão urbana (lixo, esgoto e ausência de saneamento) e pelas atividades industriais. A disputa por água doce pode agravar ainda mais as condições da pesca estuarina na vila. Segundo a entrevistada F. (2010), marisqueira, "[...] há uns 40 anos atrás a água do rio Doce era usada pra gente tomar banho, lavar vasilhas e as roupas quando a água estava clara, mas depois que construíram umas barragens rio acima acabou o rio, agora está cheio de ilhas, a água suja $[\ldots]^{\prime \prime}$.

Além das barragens, que impactam o rio Doce e, por conseguinte a pesca estuarina e a vida em Regência, segundo Meirelles e Calazans (2006), também foi construído o canal de derivação de água, chamado de Caboclo Bernardo, em benefício da Aracruz Celulose (Fibria). Com isso, esta empresa ampliou a sua capacidade de produção para 2 milhões de toneladas/ano e, em consequência dessa ampliação, em 1999 foram construídos mais de 50 km em canais abertos, interligando o rio Doce à bacia do rio Riacho, passando pelo rio Comboios, compondo o complexo hidráulico da Aracruz Celulose. 
Fotografia 8: Plantação de eucalipto da Fibria

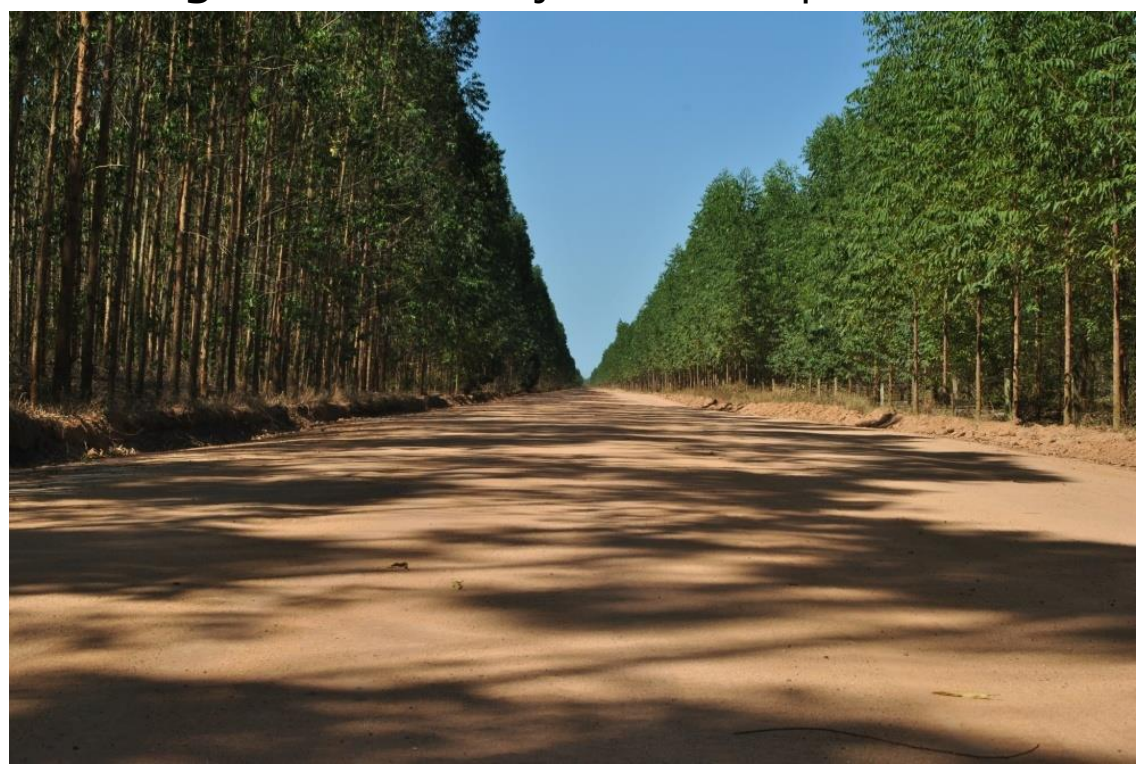

Foto: Charlene Bicalho. Regência/ES em 28/09/11.

Retomando a fala da entrevistada F. (2010), podemos apontar que a implantação de grandes empreendimentos próximos ao rio Doce tem trazido interferências diretas na vida do rio, em seus recursos naturais estuarinos e, enfim, para a comunidade de pescadores. Essas interferências são geradas por grandes projetos de infraestrutura e atividades industriais que visam tão somente o desenvolvimento econômico, esquecendo-se de levar em conta os impactos socioambientais (SILVEIRA, 2011). Ainda segundo este autor, tais empreendimentos produzem graves consequências para as comunidades tradicionais, que, por sua vez, não conseguem fazer valer seus direitos devido à força do discurso desenvolvimentista evocado por aqueles que detêm o poder político. Dessa forma, os pescadores artesanais ribeirinhos vêm sofrendo com a poluição das águas dos rios e esses impactos cobram-lhes novas formas de ação e posicionamentos sociais, fazendo-os repensar suas histórias de vida e seus modos de trabalho.

Essa poluição do rio Doce, dentre outros fatores, tem impulsionado os pescadores a buscarem outras formas de inserção no mercado de trabalho, nos chamados empregos com carteira assinada. Outra opção praticada pelos mesmos é a pesca marítima e a busca de pesqueiros cada vez mais longe da costa. Todavia os estudos sísmicos, para a prospecção de petróleo, realizados pela Petrobrás na localidade, têm excluído e restringido o uso do espaço 
marítimo para realização das seguintes modalidades realizadas no mar: rede de espera ${ }^{26}$; espinhel de anzóis ${ }^{27}$; arrasto $^{28}$ e linha de mão.

Essas alterações no ambiente marinho, advindas desses estudos sísmicos, têm emergido para o espelho d'água, alterando as técnicas de produção pesqueira e as práticas sociais dessa comunidade. No cotidiano da pesca os pescadores já conseguem identificar e perceber certas mudanças, sobretudo no que diz respeito à diminuição do volume de pescado e ao afugentamento dos pesqueiros. No relato do pescador B. (2010), encontramos um desabafo com relação aos impactos causados por esses grandes empreendimentos econômicos:

Antes de existir a Petrobras existia o pescador, mas ela tá tomando conta de tudo, vai virar escravidão daqui uns dias. Ela e a Aracruz acabam com o rio Doce! E o pescador? Se depender da Petrobras a gente morre, o pescador tem que se virar. E depois é o pescador que acaba com os peixes (B., pescador).

Por conta das alterações nas condições naturais, no caso o assoreamento $^{29}$ do rio Doce, por exemplo, aliadas ao crescimento da população, da sobrepesca, da chegada dos atravessadores ${ }^{30}$, dentre outros fatores, surgiu, entre os pescadores, a necessidade de aumentar o volume da captura dos peixes. As técnicas e o material usado na pesca também acompanharam o processo de transformação. Nesse sentido, o relato do entrevistado G. (2010), adensa essa colocação. Segundo ele: "[...] antes era bom, tinha pouca gente em Regência, então a gente pescava, descansava e consertava rede $[\ldots]^{\prime \prime}$.

Nota-se, além do aumento do número de pescadores na localidade, também o maior acesso aos materiais utilizados nas pescarias. De acordo com o entrevistado I. (2011), funcionário da Prefeitura Municipal de Linhares, há

\footnotetext{
26 Mesma modalidade realizada no rio Doce.

27 Nessa modalidade utilizam-se pedras que se colocam flutuadores em conexão com a linha principal. O flutuador possui sempre uma bandeira para facilitar a localização. A distância entre uma linha secundária e outra, deve ser suficiente grande para evitar o entrelaçamento de anzóis uns com os outros. O comprimento da linha principal é em consequência do número de anzóis, pode ser até de quilômetros e de centenas de anzóis e neste caso há necessidade de se usar um maior número de flutuadores e âncoras.

${ }^{28}$ Pesca de camarão.

29 O assoreamento e a erosão nas margens do rio formam bancos de areia dificultando a navegação e a atracagem dos barcos no porto.

30 Pessoas que compram o peixe na mão dos pescadores para comercializá-lo em outros locais.
} 
cerca de vinte anos os ônibus não passavam dentro da vila de Regência, sendo necessário percorrer um longo caminho para chegar até o ponto de ônibus, caso se quisesse ir até Linhares fazer compras. Atualmente o ônibus entra na vila, circulando em três horários durante o dia. Observa-se que o valor da passagem para Linhares aumenta o custo das pescarias, sobretudo para a manutenção dos barcos.

O saber naturalístico, peculiar aos grupos pesqueiros e às populações tradicionais, também tem sofrido alterações. Em Regência está havendo mudança na entrada da foz do rio, o que altera a rota e o tráfego de barcos. Os mestres ficam atentos a essas alterações, as quais por sua vez são compartilhadas com os demais a partir de referências já conhecidas como: o farol, Ponta da Aninga ${ }^{31}$, Ilha do Cabrito. Não menos comuns são os troncos encalhados próximos à foz do rio Doce. Quando a maré está cheia eles ficam submersos colocando em risco as embarcações e consequentemente toda a tripulação. Dessa forma, o mestre tem que saber onde estão localizados os obstáculos para poder desviar.

Fotografia 9: Ilhas no meio do rio Doce devido ao assoreamento

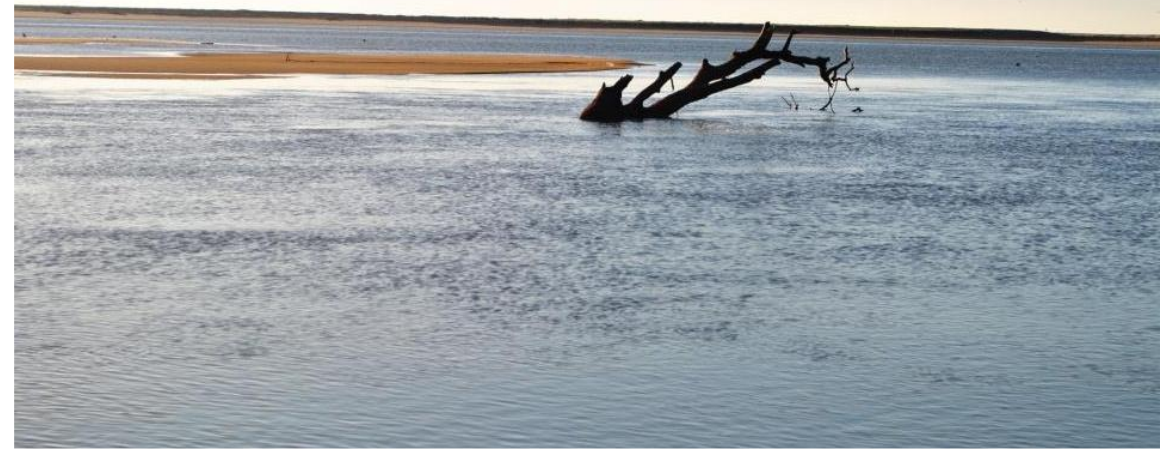

Foto: Charlene Bicalho. Regência/ES em 30/07/11.

31 Planta pioneira na formação de ilhas, principalmente às margens dos rios. 
Assim, as pescarias em Regência Augusta caracterizam-se pelo ir e vir diário para o mar. Tal fato sinaliza a mudança no trabalho, atrelada à importância da área de pesca marítima para os mesmos. Segundo o relato do entrevistado B. (2010), funcionário do Projeto Tamar, ao falar da pesca estuarina e da pesca no mar, diz: "[...] eu tô cansado de falar com eles, vocês tem que deixar de fazer pescaria de menino e fazer pescaria de homem, ir para o mar, a pesca tem que dar um salto [...]". Todavia, vale lembrar que quando estes chegam ao mar são pressionados pelas restrições da área de pesca.

A complexidade com que se promovem e são vivenciadas tais alterações no cotidiano da cidade e na vida de seus moradores, não nos permite pensá-las apenas sob o enfoque de um único fator determinante, ou de uma só causa, como comumente nos ensinam as abordagens sociológicas mais clássicas (VALADE, 1995). Como já foi exposto anteriormente, trata-se de um misto de elementos, tanto endógenos quanto exógenos que inquietam, interferem e movimentam a vida local. Podemos perceber essas mudanças sociais quando observamos os aspectos macrossociais e também quando adentramos os processos interativos da vida diária.

Uma análise a partir dos aspectos macrossociais da mudança social nos levaria a ressaltar os efeitos dos processos modernizadores que têm invadido a vida comunitária daquele grupo, redesenhando sua estrutura. $O$ enfoque seria dado aos impactos socioambientais dos grandes projetos de desenvolvimento (a Petrobrás, a Aracruz Celulose - atual Fibria, dentre outros), que alteram os modos de vida e de trabalho naquela localidade, conforme já narrado. Entretanto, as mudanças também podem ser enxergadas no universo microssocial, nos processos interativos e na dimensão da cultura local. Se pensarmos que "o cotidiano também se constitui de rupturas, e não apenas de regularidades normativamente esperadas" (LEITE, 2010, p. 740), podemos ver nas dinâmicas interativas também uma capacidade de transformação, sobretudo a partir do modo como as pessoas pensam, ressignificam e constroem as suas vidas diárias juntas umas com as outras. Nesse caso, as crenças e o imaginário simbólico que organizam a vida dos habitantes da pequena vila também são dimensões importantes de observação e análise.

Sendo assim, tomemos rapidamente as novas gerações, esse grupo social tão peculiar. Nos jovens podemos ver sinalizado o quanto de reprodução e de transformação social coexistem em um ambiente cotidiano. Sabe-se que em Regência Augusta as ruas, as casas e as festividades são permeadas direta ou indiretamente pelas referências à pesca, não obstante as alterações locais, 
advindas dos já citados processos modernizadores. Compreender, por conseguinte, como esse encontro do antigo e do novo se reproduz e transforma na percepção dos mais jovens, abre espaço para algumas reflexões acerca dos processos de mudança social e seu potencial para produzir efetivas rupturas.

As novas gerações de Regência 32 ilustram, no seu universo simbólico e nas suas escolhas práticas, uma tendência à alteração nos seus modos de vida em relação à história de seus pais e avós, inclusive no trato da atividade pesqueira. O universo da vila, já permeado por elementos urbanos - o contato com as novas tecnologias de comunicação e informação, a presença de outras atividades de trabalho (comércio, turismo, indústrias) -, traz a possibilidade de novos encaixes sociais na construção biográfica destes jovens.

Nesse universo que conforma a relação do jovem com a pesca, observase que quando estes assumem a continuidade da atividade de seus pais e avós como sua principal atividade de trabalho e fonte de renda, já o fazem optando pela pesca marítima ao invés da estuarina (privilegiada ainda pelos mais antigos). Por conta dos impactos na foz do rio Doce, já narrados alhures, a alternativa da pesca marítima tem se configurado como saída para a atividade. Tal mudança é percebida na escolha dos mais jovens pela pesca de espinhel (que é realizada no mar) à de rede de espera (realizada no rio). Esse fato tem gerado um conflito geracional, no qual as outras modalidades de pescaria são vistas pelos mais jovens como ultrapassadas. Assim, o entrevistado N. (2011) disse, quando questionado se seu pai não ligava dele ir pescar em outro barco: "[...] nada, meu pai não liga não, a pesca dele é pesca de velho, só fica ali no rio $[\ldots] "$.

Esse dado, ou seja, a preferência pela pesca marítima, revela como as mudanças e as rupturas acontecem em Regência Augusta, sendo filtradas agora a partir dos argumentos discursivos, e porque não dizer reflexivos, desses jovens pescadores. Tais alterações nos modos de fazer deste ofício parecem-nos passíveis de repercutir também em alterações no cotidiano da vila, na vida familiar, nas formas de apropriação do espaço e dos recursos, assim como no universo simbólico da pesca. Lançar-se ao mar para os mais jovens exige novos enfrentamentos, outras indeterminações, bem diferentes daqueles vividos na pesca estuarina.

32 Mantivemos contato com alguns jovens, junto aos quais pudemos colher algumas impressões. 
Dessa forma, a pesca artesanal de Regência tem sido palco de mudanças e de ressignificações por parte de seus agentes. Alguns chegam a dizer que a pesca artesanal está fadada ao envelhecimento, tendo em vista que as novas gerações optam, muitas vezes, pela via formal do emprego em detrimento da atividade pesqueira.

Entretanto, o saber naturalístico adquirido no ofício da pesca desde tempos remotos, embora se altere - por conta dos inúmeros impactos socioambientais sofridos e pela capacidade de agência e inovação dos mais jovens e também dos mais velhos - ainda permanece. É um bailado complexo esse, o da relação entre o cotidiano e as alterações e rupturas nele produzidas. Observam-se, nesse movimento, as fissuras e permanência da pesca tanto como prática quanto como memória: nas brincadeiras de criança, nas pequenas mãos que aprendem, através do lúdico, essa mediação entre o universo humano e o universo natural. É desse modo que pensamos ser difícil medir ou precisar onde estaria o fim dessa realidade de vida, e em que ponto esta mesma realidade permanece enquanto início, ou renovação.

Fotografia 10: Júnior brincando de pescaria dentro de uma canoa em terra

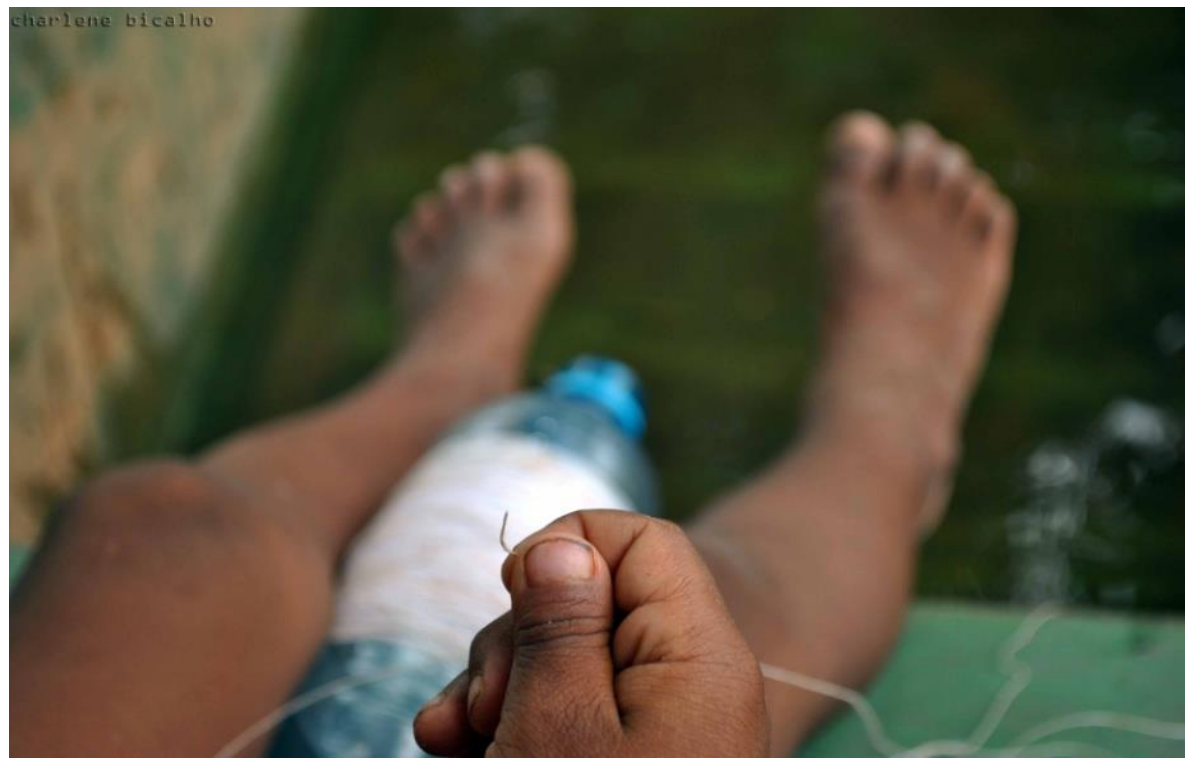

Foto: Charlene Bicalho. Regência/ES em 07/03/11. 


\section{Águas que ficam e passam: evitando oclusões}

É no próprio fazer cotidiano que as transformações sociais se instauram. Por meio desse jogo interativo e dinâmico entre o instituído e o novo, entre os fazeres rotinizados e as contingências emergentes, as significações vão sendo atualizadas, assim como as práticas humanas. No ofício da pesca um elemento a mais colabora dando fôlego a essa dinâmica: as condições ambientais. Os ventos, a chuva, o mar, o rio, os peixes, a escassez ou a abundância destes, os impactos e pressões sobre tais recursos, são aspectos importantes para a atividade pesqueira. As redes de sociabilidade dos pescadores, os seus instrumentos de trabalho, os saberes transmitidos, nada disso existe apartado das condições ambientais. A natureza, nesse sentido, destaca-se como o corpo sem órgãos do pescador, sua extensão, sem a qual não seria possível a sua reprodução social.

Fotografia 10: Pescador Monstro limpando o peixe

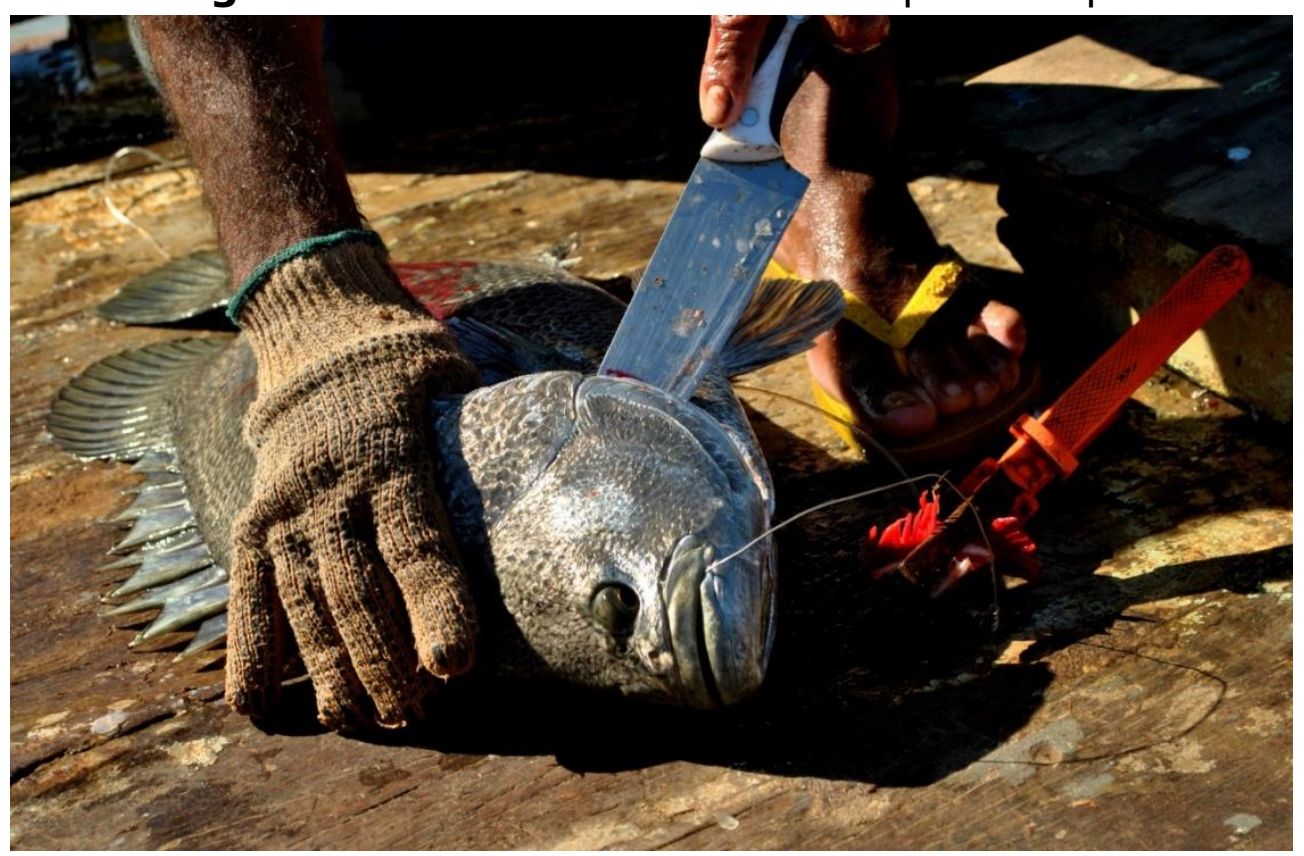

Foto: Charlene Bicalho. Regência/ES em 16/07/11.

As mãos, por sua capacidade de criação e transformação do mundo, dão moldura a essa atividade interativa com a natureza. No entanto, nessa 'ecologia' da pesca não somente o corpo do pescador, mas também o seu olhar, encontra-se impregnado pelas paisagens de mar e de rio, paisagens de 
memória (SCHAMA, 1996), e por certos modos de fazer e de saber. É, pois, nesse movimento das águas que a carga da história é transportada.

Fotografia 11: Mestre Cuíca (in memorian), conduzindo a embarcação Nova Vida enquanto auxilia no direcionamento do espinhel.

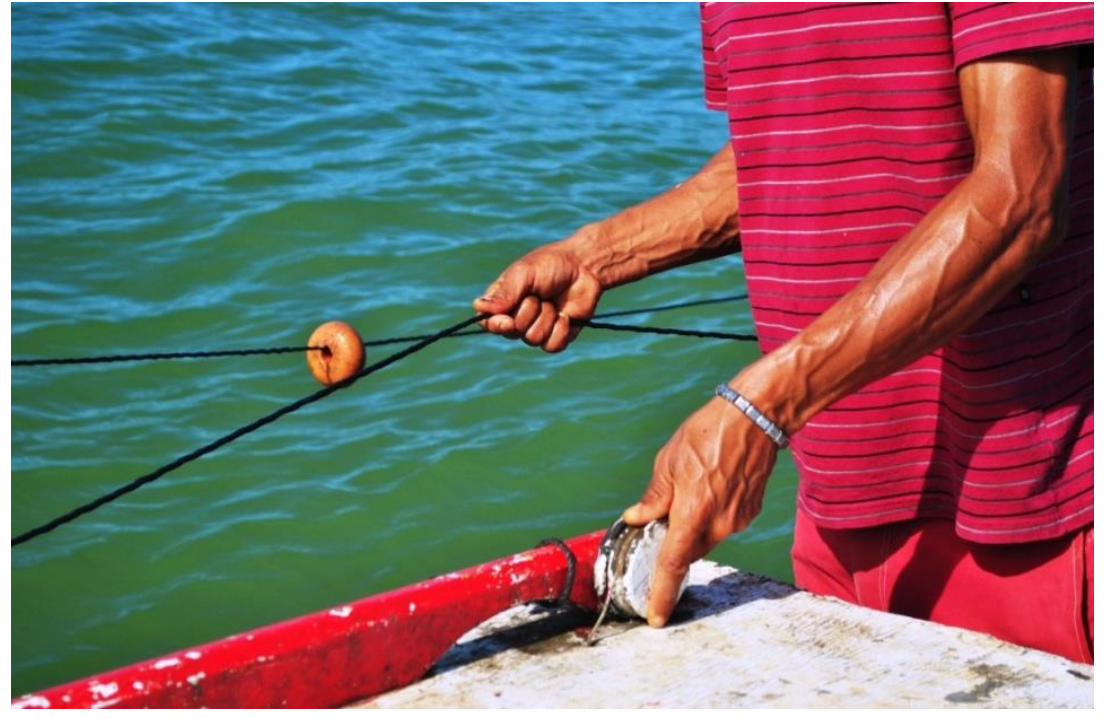

Foto: Charlene Bicalho. Regência/ES em 16/07/11.

É ainda nesse movimento das águas que se processam as alterações no cotidiano da vila de Regência, sobre as quais tentamos contar aqui um pouco. A cidade, o rio, o mar, as paisagens, tornam-se lugares abertos aos encontros sociais e também às perdas. Com isso, o cotidiano se faz enquanto movimento, como imprevisibilidade e normatividade (LEITE, 2010), ruptura e continuidade.

Tais experiências vividas são também processos de ressignificação não apenas para aqueles que foram fotografados, mas para a própria fotógrafa. Uma experiência de ruptura entre aquilo que a lente capturou e o que ela deixou extravasar para além da moldura da câmera. Durante o exercício prático da vida cotidiana, naquele contato com os pescadores em Regência Augusta, o que se tentou captar e entender foram os modos como a atividade da pesca (e com isso a dinâmica social da pequena vila) ia se alterando, ao mesmo tempo em que permanecia a mesma.

Assim é que, no movimento dessas águas caboclas, vão sendo tecidas as histórias de vida desses pescadores e pescadoras, dessas pessoas comuns, que, na simplicidade do seu dia a dia, revelaram-nos as suas alegrias e angústias, os seus dramas e a magia de suas festividades... Ali naquelas águas que ficam e que passam... 
Fotografia 12: Mestre Flor retirando rede de espera do rio Doce

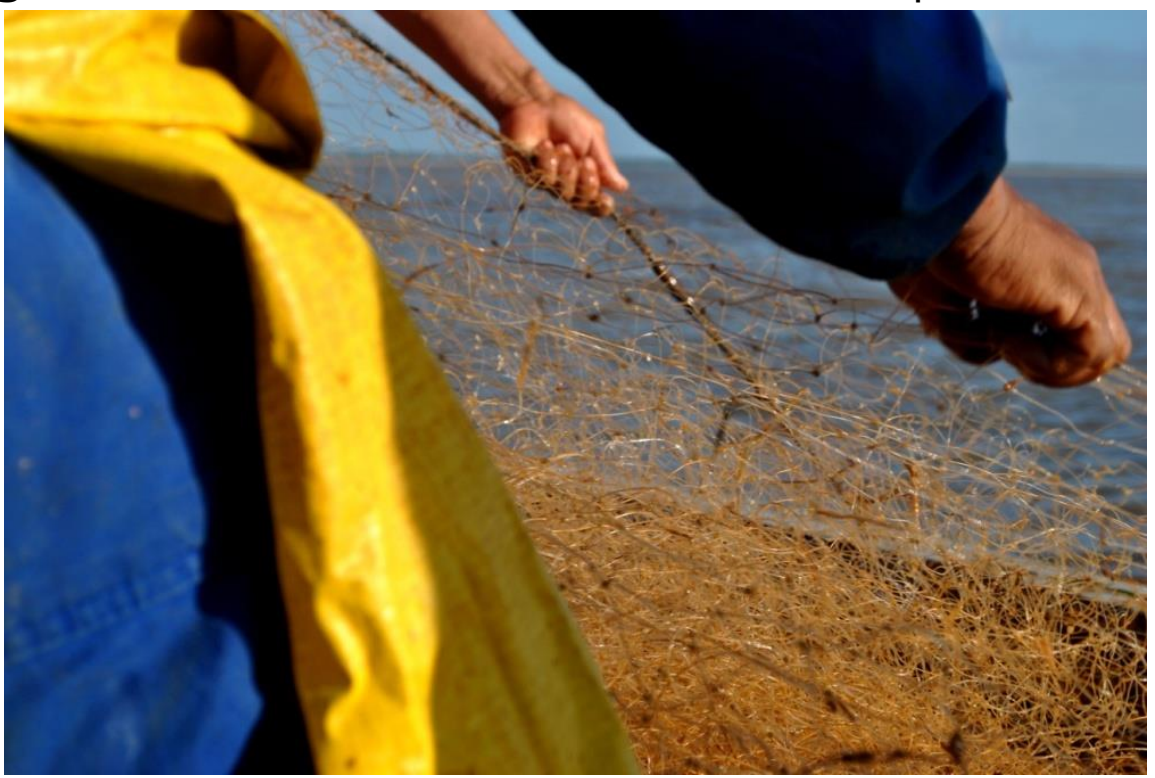

Foto: Charlene Bicalho. Regência/ES em 14/07/11.

Fotografia 13: Pescadores Bachá e o Mestre Bebeto puxando o balão

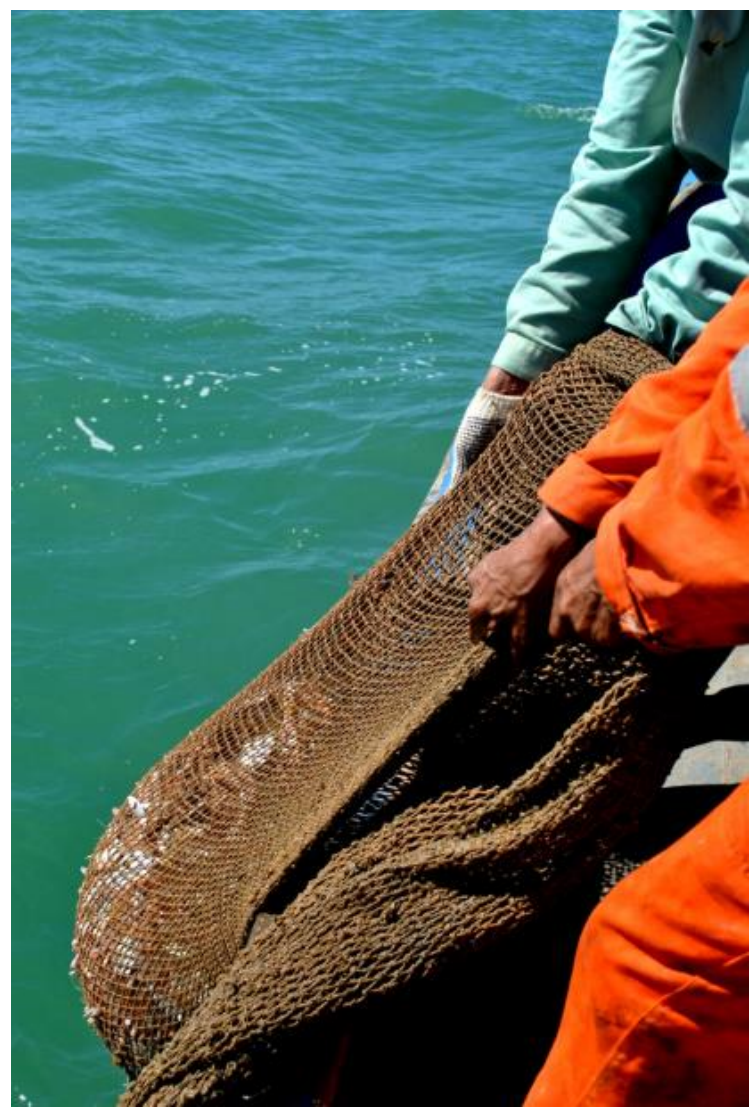

Foto: Charlene Bicalho. Regência/ES em 16/09/11. 


\section{Referências}

ALVES, André. Os Argonautas do Mangue. São Paulo: Ed. Unicamp/imprensa oficial, 2004.

BICALHO, C. S. Além da superfície: um estudo sobre os impactos do desenvolvimento na pesca artesanal de Regência Augusta - ES. Dissertação (Mestrado em Administração). Universidade Federal do Espírito Santo-UFES, Vitória, 2012.

BITENCOURT, Luciana. A fotografia enquanto instrumento etnográfico. Anuário Antropológico, Rio de Janeiro, v. 92, p.225-241, 1994.

BRITTO, Rosyan. Modernidade e tradição: construção da identidade social dos pescadores de Arraial do Cabo - RJ. Niterói: UFF, 1999.

CRANE, J.; ANGROSINO, M. Fields projects in Antropology - a student handbook. 2 ed. Illinois: Waveland Press, Inc., 1984.

COLLIER Jr., John; COLLIER, M. Visual anthropology: photography as a research method. Revised and expanded edition. Albuquerque: University of New Mexico Press, 1986.

DESCOLA, P. Ecologia e cosmologia. In: Diegues, A. C. Etnoconservação (Org.) $2^{a}$ ed. São Paulo: Anablume, 2000.

DIEGUES, Antônio Carlos. A sócio-antropologia das comunidades de pescadores marítimos no Brasil. Etnográfica, Lisboa, v. 3, p. 361-375, 1999.

GEERTZ, C. O saber local: novos ensaios em antropologia interpretativa. Petrópolis: Vozes.

GODOLPHIN, N. A fotografia como recurso narrativo: problemas sobre a apropriação da imagem enquanto mensagem antropológica. In: Horizontes Antropológicos. Porto Alegre, ano 1, n. 2, p.125- 142, 1995.

KANT, R. DE L. Pescadores de Itaipú: meio ambiente, conflito, ritual e pesca. Niterói: Ed. UFF, 1997.

KEYES, C. F. The observer observed Changing Identities of ethnographers in a Northeastern Thai Village. In LAWLESS, R.; SUTLIVE, V.J.; ZAMORA, M. Fieldwork: The human experience. London: Gordon Beach, Science Pub., 1983.

KNOX, W.; CORADINI, Lisabete. Imagens e espelho: reflexões sobre o uso da fotografia em comunidades pesqueiras. Cadernos de Antropologia e Imagem (UERJ), v. 1, p. 35-47, 2007.

KNOX, W. Vivendo do mar: modos de vida e de pesca. 1. ed. Natal: Edufrn. v. $1,2009$. 
KNOX, W. A imagem fotográfica: observando e observada. In: Lisabete Coradini e Francisca Miller (Org.). Imagem e meio ambiente: debates atuais. Natal: EDUFRN, p. 55-81, 2011.

LAWLESS, R.; SUTLIVE, V. J.; ZAMORA, M. Fieldwork: The human experience. London: Gordon Beach, Science Publ, 1983.

LEITE, M. L. M. Texto visual e texto verbal. In: FELDMAN-BIANCO, B.; LEITE, M. M. (Org.). Desafios da imagem: fotografia, iconografia e vídeo nas Ciências Sociais. São Paulo: Papirus, 1998.

LEITE, Rogerio Proença. A inversão do cotidiano. Práticas sociais e rupturas na vida urbana contemporânea. DADOS - Revista de Ciências Sociais, Rio de Janeiro, vol. 53, no. 3, p. 737 a 756, 2010.

MARTINS, José de Souza. Sociologia da fotografia e da imagem. São Paulo: Contexto, 2011.

MEAD, Margaret. Visual Anthropology. In: A discipline of words, principles of visual anthropology. $2^{\text {th }}$ ed. Le Hague, Mouton, EU, 1995.

MEIRELLES, Daniela; CALAZANS, Marcelo. H2O para celulose $x$ água para todas as línguas: o conflito ambiental no entorno da Aracruz Celulose S/A Espírito Santo. [S.I.: s.n.], 2006.

SILVEIRA, Pedro Castelo Branco. Pesca artesanal, territórios e os impactos dos grandes empreendimentos. Coletiva, [S.I.], n. 3, jan/fev/mar. 2011. Disponível em: <www.coletiva.org>. Acesso em: 28 de junho de 2011. VALADE, Bernard. Mudança Social. In: BOUDON, Raymond (Dir.). Tratado de Sociologia. Rio de Janeiro: Jorge Zahar Editor, 1995.

ROUÊ, M. Novas perspectivas em etnoecologia: "saberes tradicionais" a gestão dos recursos naturais. In: Diegues, A. C. Etnoconservação (Org.). $2^{\mathrm{a}}$ ed. São Paulo: Anablume, 2000.

SAMAIN, E. Oralidade, escrita, visualidade. Meios e modos de construção dos indivíduos e das sociedades humanas. In: JUNQUEIRA FILHO, L. C. (Org.). Perturbador mundo novo: história, psicanálise e sociedade contemporânea 1492-1992. São Paulo: Escuta, 1994a, p. 289-301.

. Para que a Antropologia consiga tornar-se visual. In: FAUSTO NETO, A. (Org.) Brasil, comunicação, Cultura e Política. Rio de Janeiro: Diadorim Ed., 1994b, p. 33-46

SCHAMA, Simon. Paisagem e memória. São Paulo, Companhia das Letras, 1996.

ZUNTI, Maria Lucia Grossi. Panorama histórico de Linhares. Linhares: Prefeitura Municipal de Linhares, 1941. 